\title{
Quantitative measurement of toxic metals and assessment of health risk in agricultural products food from Markazi Province of Iran
}

\author{
Fereshteh Karimi ${ }^{1}$, Nabi Shariatifar ${ }^{1 *}$ (D), Mohammad Rezaei ${ }^{1}$, Mahsa Alikord ${ }^{1}$ and Majid Arabameri ${ }^{2}$
}

\begin{abstract}
The current study aims to investigate the levels of the toxic metal in agricultural products (legumes, wheat, and potato) collected in Markazi province, Iran, and human health risk by using inductively coupled plasma - optical emission spectrometry (ICP-OES). The levels of arsenic (As) and cadmium (Cd) in all samples were lower than the limit of detection (LOD), while the level of $\mathrm{Cd}$ in potato samples was lower than the maximum permisible level (MPL) of the European commission (EC). The non-carcinogenic and carcinogenic risk assessment by direct ingestion of agricultural products was calculated using the United States Environmental Protection Agency (USEPA) method. The highest mean of toxic metals was observed for lead $(\mathrm{Pb})$ in legume samples $\left(562.17 \mathrm{\mu g} \mathrm{kg}^{-1}\right)$. Mercury $(\mathrm{Hg})$ and $\mathrm{Pb}$ levels in all samples were higher than LOD, while $\mathrm{Pb}$ level in wheat samples were lower than of $\mathrm{EC}$. The rank order of $\mathrm{Hg}$ and $\mathrm{Pb}$ levels in all samples based on target hazard quotient (THQ) value was wheat> potato >legume. The THQ index of $\mathrm{Hg}$ and $\mathrm{Pb}$ by the deterministic method in wheat was 1.37 and 0.454 ; in potato 0.139 and 0.104; in legume 0.092 and 0.41 , respectively. The carcinogenic risk index was at an acceptable range. The high hazard index values were estimated and the THQ index for $\mathrm{Hg}$ in wheat suggests a non-negligible health risk.
\end{abstract}

Keywords: Agricultural products, Health risk assessment, Toxic metals, ICP-OES

\section{Introduction}

Agricultural products are an important part of the human daily diet that can be contaminated with toxic metals such as $\mathrm{Hg}, \mathrm{Cd}, \mathrm{Pb}$, and As, therefore agricultural products are considered a serious concern for human health (Stefanović et al. 2008; Dodangeh et al. 2018). The contamination of agricultural products with toxic metals can be related to either environmental resources or human activities such as industrial processing, mining, waste disposal, application of wastewater, sewage sludge to irrigation of cultivated agricultural products,

\footnotetext{
* Correspondence: nshariatifar@ut.ac.ir

'Department of Environmental Health Engineering, School of Public Health, Tehran University of Medical Sciences, Tehran, Iran

Full list of author information is available at the end of the article
}

and even application of fertilizers (especially phosphate type) and pesticides (Tadesse et al. 2015; MarrugoNegrete et al. 2015; Shariatifar et al. 2020; Shariatifar et al. 2017). It is worthy to note that the atmospheric deposition could be accounted as the primary sources of soil, and water contaminations and consequently further contaminations in the food chain (Fakhri et al. 2017). In this regard, agricultural products can absorb toxic metals from the soil, water, and air, furthermore concentrate them in different parts such as roots, leaves, and grains (Qu et al. 2012).

Toxic metals as the non-essential compounds for the human body could cause several adverse health effects, even in trace amounts (Yllmaz et al. 2010). Due to their non-degradable nature, they could biologically 
accumulate in different tissues (kidney, liver, bone, and brain) after their intake through diet as well as inhalation pathways (Bjørklund et al. 2017; Raj and Maiti 2019). It has been noted that developmental disorders in infants and children such as lowering intelligence quotient (IQ) can be correlated with $\mathrm{Hg}$ and $\mathrm{Pb}$ (MarrugoNegrete et al. 2015; Raj and Maiti 2019). In this context, the International Agency for Research on Cancer (IARC) categorized $\mathrm{Pb}$ as (group 2B) and $\mathrm{Cd}$ as (group 1) a human carcinogenic compound (Cancer IAfRo 1993). As may cause cancer in humans in various organs including the lung, skin, blood, and skeleton. (Sarkar and Paul 2016). Also, excessive entry of heavy metals and synthetic chemicals into the studied soils may lead to deterioration of the soil biology, thereby altering the physicochemical properties of the soil and causing other environmental problems $(\mathrm{Qu}$ et al. 2012; Salama and Radwan 2005; Islam et al. 2020; Proshad et al. 2018; Solgi et al. 2014; Solgi et al. 2012; Ghasemidehkordi et al. 2018a; Ghiyasi et al. 2010a; Hani and Karimineja 2010a). Pruvot et al. (2006) showed that the soil near the smelter is more contaminated than the reference soil. Also, higher levels of toxic metals in industrial and mining areas are due to lack of environmental protection and pollution (Pang et al. 2016; Fang et al. 2014). Agrawal et al. (2003) noted that agricultural lands near industrial centers and highways should also be polluted due to air pollution around them (Agrawal et al. 2003). Therefore, atmospheric sedimentation in agricultural lands located in industrial areas might play a critical role in the uptake of higher levels of toxic metals by plants (Rahman et al. 2013). Moreover, industrialization influences the toxic metals concentration in soil, water, and air leads to an increase in the concentration of these elements in agricultural products. Lei et al. (2015) mentioned that human activities, like mineral exploration, refining, and manipulation, as well as sewage sludge, are the most important sources of toxic metals pollution (Lei et al. 2015).

In Markazi province, the presence of heavy metals in the soil may be from various sources such as industrial activities, lead and zinc mines, and fuel combustion, greenhouse gas emissions, and municipal waste disposal. To the best of our knowledge, few researches have been done to investigate the concentration of toxic metals in agricultural products, obtained from the industrial areas of Markazi province as one of the most industrialized regions of Iran. Also, this is the first attempt to measure and compare toxic metal content in agricultural products in the industrial areas of Markazi province using an ICP-OES. Therefore, the present study is devoted to evaluate the toxic metal concentrations and the potential health effects in selected agricultural products (legumes, potatoes, and wheat) in Markazi province of Iran.

\section{Method and material}

\section{Chemical reagents}

All chemicals (nitric acid 65\%, perchloric acid, sulfuric acid, and hydrogen peroxide $70 \%$ ) and standard stock solutions of toxic metals with analytical grade (purity > 99\%) were purchased from Merck (Darmstadt, Germany). Double-distilled water was used in all dilutions.

\section{Sample collection}

The sample size was based on the agricultural fields. In this regard, the samples were collected in January 2019 from agricultural products produced in the Markazi Province. A total of 120 samples were collected (60 samples of legume (chickpea $(n=20)$, lentil $(n=20)$ and bean $(n=20), 30$ samples of potato, and 30 samples of wheat were collected). All samples were labeled after collection and stored in clean polythene bags according to their type and then transfer to the laboratory for analyses.

\section{Preparation and treatment of samples}

The collected samples were washed with distilled water to eliminate possible surface contamination. Then the potato samples were cut into small pieces with a knife and then all the samples were dried in an oven at $100{ }^{\circ} \mathrm{C}$. Finally, the samples were grinded into a fine powder using a commercial blender and stored in polyethylene bags, until analysis.

\section{Sample preparation}

To minimize effects of organic matrix and prevent the possibility of sample contamination and loss of analyte, in this study acid decomposition of samples was performed in the closed vessel microwave oven system (Milestone Ethos D, maximum power of $1400 \mathrm{~W}$ and maximum pressure in Teflon vessels of 100 bar). The agricultural product samples were washed with distilled water and dried at $105^{\circ} \mathrm{C}$ for $48 \mathrm{~h}$. The dried samples were ground, then homogenized using an agate pestle, and sorted in glass bottles until analysis. All of the glass containers used were cleaned and soaking, overnight in a $10 \%$ nitric acid solution, and then rinsed with deionized water (Türkmen and Dura 2016; Mendil et al. 2004). Triplicate agricultural product samples $(0.25 \mathrm{~g})$ were digested with $9 \mathrm{~mL}$ of nitric acid $(65 \%)$ and $1 \mathrm{~mL}$ of hydrogen peroxide $(70 \%)$ in the microwave digestion system for $30 \mathrm{~min}$ at a maximum temperature of $300{ }^{\circ} \mathrm{C}$. The residue was then diluted to $10 \mathrm{~mL}$ with deionized water in a $10 \mathrm{~mL}$ volumetric flask. A blank digest was conducted in the same way (Türkmen and Dura 2016; Torres-Escribano et al. 2010). 


\section{ICP-OES measurement}

All prepared samples were analyzed in triplicates using an ICP-OES (Spectro Arcos, SPECTRO, Germany) with Torch type of flared end EOP Torch $2.5 \mathrm{~mm}$. The optimum functioning parameters were radio-frequency (RF) generator $(1400 \mathrm{~W})$; argon gas grade 6 was used for plasma, nebulizer, and auxiliary gas. The gas flows of plasma, auxiliary, and nebulizer were 14.50, 0.90, and 0.85(L min -1), respectively. Then, initial stabilization time, rinse time, and sample uptake time were $240 \mathrm{~s}$ total and $45 \mathrm{~s}$ for preflush. Also, the time between replicate analysis and delay time was zero. The analysis was a three-time replicate, and the frequency (resonance frequency) of the generator of RF was $27.12 \mathrm{MHz}$. The types of solid state, detector, and spray chamber were cyclonic,, Charge Coupled Device (CCD), and modified Lichte, respectively. The type of pump of sample delivery was four-channel, software-controlled; peristaltic pump enables exact sample flows. The speed of prewash pump was $60 \mathrm{rpm}$ (for15 s), $30 \mathrm{rpm}$ (for $30 \mathrm{~s}$ ), and the time of prewash was $45 \mathrm{~s}$, and finally, the speed of the pump of sample injection was $30 \mathrm{rpm}$.

\section{Validation of the analytical method}

The validation of the analytical procedure for quantitative analysis of elements in agricultural products and its aqueous extracts was performed by evaluating selectivity, working and linear ranges, LOD, quantification limit (LOQ), re-peatability, and reproducibility (precision). Matrix effects were studied using standard addition method, by adding $200 \mu \mathrm{L}$ of mixed standard solutions to the original samples (Mix standard certified reference material (CRM): 92091 Supelco LOT BCCB9855, Trace $\mathrm{CERT}^{\bullet}, 33$ elements, $10 \mathrm{mgL}^{-1}$ in nitric acid, $\mathrm{Hg}$ standard CRM:28941 Supelco, LOT BCCB8927, $1000 \mathrm{mgL}^{-1}$, $\mathrm{Hg}$ in nitric acid). The recovery values were in the 94$105 \%$ range.

\section{Health risk assessment}

The Chronic Daily Intake (CDI) of detection of toxic metals due to ingestion of toxic metals via consumption of food products was calculated using the following Equation (Heshmati et al. 2018; Jahanbakhsh et al. 2019):

$$
\mathrm{CDI}=\frac{\mathrm{C} \times \mathrm{IR} \mathrm{i} \times \mathrm{EDi} \times \mathrm{EFi}}{\mathrm{BW} \times \mathrm{AT}}
$$

In this study, $\mathrm{C}$ is the concentration of the toxic metal $\left(\mathrm{mg}^{\mathrm{kg}}{ }^{-1}\right)$; IRi ingestion rate was set as (legume $19 \mathrm{~g}$ day $^{-1}$, wheat $320 \mathrm{~g} \mathrm{day}^{-1}$ and potato $58 \mathrm{~g} \mathrm{day}^{-1}$ ) (Abdollahi et al. 2014; Kalantari et al. 2005); EDi is the exposure duration of toxic metals ingestion (24 years); EFi, is the exposure frequency (350 days year ${ }^{-}$) (Yousefi et al. 2018); BWI, bodyweight average (70 Kg) (Yousefi et al. 2018; Nazaroff and Alvarez-Cohen 2001) and AT is the mean exposure years ( 365 days year ${ }^{-1} \times$ number of exposure years) (EPA U 2015). The THQ was used for the non-carcinogenic risk assessment of toxic metals according to Eq. 2(Dadar et al. 2017; Madani-Tonekaboni et al. 2019; Roudbari et al. 2021):

$$
\mathrm{THQ}=\frac{\mathrm{CDI}}{\mathrm{RfD}}
$$

Where, CDI is chronic daily intake $\left(\mathrm{mg} \mathrm{kg}^{-1}\right.$ per day); $\mathrm{RfDo}$ is the oral reference dose that for $\mathrm{Hg}, \mathrm{Pb}$ and $\mathrm{Cd}$ are $0.0001,0.0035$, and $0.0005 \mathrm{mg} \mathrm{kg}^{-1}$ per day (EPA U 2015; Dadar et al. 2017; Madani-Tonekaboni et al. 2019; Rezaei et al. 2013).

The carcinogenic risks (CR) for exposure to $\mathrm{Pb}$ to the population in were obtained using the Eq. 4 (Yousefi et al. 2018; Fakhri et al. 2018; Fathabad et al. 2018):

$$
\text { Cancer risk }(\mathrm{CR})=\mathrm{CDI} \times \mathrm{CSF}
$$

Where, CSF index is the cancer slope factor of $\mathrm{Pb}$ via agricultural products ingestion pathway $(0.00085 \mathrm{mg} / \mathrm{kg} /$ day), CSF index for $\mathrm{Hg}$ via oral ingestion was not provided. In this investigation the calculated $C R$ values, was compared with the upper limit allowed by the USEPA standards which is $\leq 10-6$ (USEPA 2016).

\section{Statistical analysis}

The statistical analysis was conducted with SPSS v.24 using analysis of variance (ANOVA) and Chi-square tests. The toxic metal contents represent the mean of three independent experiments (triplicate). Data are presented as mean \pm SEM value. The considered significant level was $p<0.05$.

\section{Results}

The graphs of calibration for the toxic metals were prepared from the standard solutions at six points, ranged from $0.50-16 \mu \mathrm{gL}^{-1}$. All the toxic metals revealed linear relationships of the instrumental response and the solutions containing the metals with insignificant intercepts and correlation coefficients for all samples ranged from 0.9891 to 0.9922 .Perceived LOD and LOQ are ranged 0 . $05-2$ and $0.16-6.60 \mu \mathrm{g} / \mathrm{kg}$, respectively. The recoveries gained were found to vary from 94 to $105 \%$ that is a suitable range for all toxic metals. The wavelengths applied for the determination of the elements concentration, based on baseline signals and their interferences at selected lines observed experimentally during the measurements (Table 1). Table 2 shows toxic metals content in legume, wheat, and potato samples in Markazi 
Table 1 Wavelength and method validation parameters obtained by ICP-OES analysis in agricultural products samples

\begin{tabular}{lllllll}
\hline Element & Wavelength $(\mathbf{n m})$ & $\mathbf{R}^{\mathbf{2}}$ Value & Calibration range & Recovery $(\%)$ & $\begin{array}{l}\text { LOD } \\
(\boldsymbol{\mu} \mathbf{g} / \mathbf{k g})\end{array}$ & $\begin{array}{l}\text { LOQ } \\
(\boldsymbol{\mu g} / \mathbf{k g})\end{array}$ \\
\hline $\mathrm{As}$ & 189.042 & 0.9922 & $0.3-1200$ & 94 & 1 & 3.30 \\
$\mathrm{Cd}$ & 214.438 & 0.9891 & $0.3-1200$ & 98 & 0.05 & 0.16 \\
$\mathrm{Hg}$ & 184.950 & 0.9899 & $0.3-1200$ & 101 & 0.35 & 1.17 \\
$\mathrm{~Pb}$ & 283.305 & 0.9918 & $1.2-1200$ & 105 & 2 & 6.60 \\
\hline
\end{tabular}

province as well as permissible levels for toxic metals. Table 3 shows the estimated THQ for toxic metals ( $\mathrm{Hg}$, $\mathrm{Cd}$, and $\mathrm{Pb}$ ) exposure through food products (legume, potato, and wheat) consumption by deterministic method in Markazi province.

Based on deterministic method, the CR index in the legume, wheat, and potatoes due to $\mathrm{Pb}$ was $1.24 \times 10^{-7}$, $1.39 \times 10^{-6}$, and $3.17 \times 10^{-7}$, respectively.

\section{Discussion}

\section{Toxic metals concentration}

The concentration of As and $\mathrm{Cd}$ in agricultural products samples (except for potato samples in the case of $\mathrm{Cd}$ ) was lower than the LOD ( 1 and $0.05 \mu \mathrm{g} \mathrm{kg}^{-1}$, respectively). For instance, the mean concentration reported for $\mathrm{Cd}$ in wheat and legume samples were lower than LOD, while in potato samples it was $27.46 \mu \mathrm{g} \mathrm{kg}^{-1}$, which were lower than the MPL proposed by EC $\left(30 \mu \mathrm{g} \mathrm{kg}^{-1}\right)$. In some of the previous studies also As, Cd concentrations were lower than other elements $(\mathrm{Hg}$ and $\mathrm{Pb})$ which probably due to the low absorption of $\mathrm{As}$ and $\mathrm{Cd}$ through the plant root compared to $\mathrm{Hg}$ and $\mathrm{Pb}$ (Cheng et al. 2017). In this study, among all food samples, the highest mean concentration of $\mathrm{Pb}$ was observed in legume samples $\left(562.17 \mu \mathrm{g} \mathrm{kg}^{-1}\right)$. which were lower than the MPL proposed by National Standard Organization of Iran $\left(300 \mu \mathrm{g} \mathrm{kg}^{-1}\right)$ (ISIRI 2000). The highest mean concentration of $\mathrm{Hg}$ was observed in wheat samples (39.54 $\left.\mathrm{\mu g} \mathrm{kg}^{-1}\right)$, which were lower than the MPL proposed by Food and Drug Administration $\left(500 \mu \mathrm{g} \mathrm{kg}^{-1}\right)$ (Food and Drug Administration (FDA) 2018). Similar studies have shown that $\mathrm{Pb}$ concentration in vegetables and crops is higher than other toxic metals, due to their high ability to absorb even small amounts of $\mathrm{Pb}$ from air, soil, and water pollution (Liu et al. 2013; Sharafi et al. 2019). However, the main source of mercury in agricultural products is through air pollution, while the uptake of mercury through soil is partial (Ghasemidehkordi et al. 2018a).

The rank of $\mathrm{Hg}$ concentration of agricultural products can be summarized as wheat' legume' potato. The rank of $\mathrm{Pb}$ concentration of agricultural products was legume potato ${ }^{>}$wheat. Although agricultural products can absorb a variety of toxic metals, there is no uniform relationship between toxic metal concentrations and food type (Fang et al. 2014). Moreover, the concentration of the toxic metal in legume samples was higher than potato samples due to the different susceptibility of vegetables to pollution. Pruvot et al. (2006) reported that the leafy vegetables had higher concentrations of $\mathrm{Pb}$ and $\mathrm{Cd}$ than potatoes (roots or tuberous vegetables) (Pruvot et al. 2006). Liu et al. (2013), reported the differences in toxic metals concentration between different plants owing to their diverse accumulation capacities and different soil characteristics (Liu et al. 2013). Momen et al. (2006) reported that the concentrations of $\mathrm{Pb}$ and $\mathrm{Cd}$ were lower than LOQ in all legume samples (except for $\mathrm{Cd}$ concentration in the white bean, faba bean, and lentil samples were 900, 800, and $500 \mu \mathrm{g} \mathrm{kg}^{-1}$, respectively) (Momen et al. 2006).

According to study of Tadesse et al. (2015), Pb concentration in potatoes of Ethiopia was in the range of $2000-17,400 \mu \mathrm{gg}^{-1}$ (higher than MPL of EC), while in the present study, the $\mathrm{Pb}$ concentration was below the LOD $\left(<100 \mu \mathrm{g} \mathrm{kg}^{-1}\right)$. A similar study have been shown that the $\mathrm{Cd}$ and $\mathrm{Pb}$ concentrations in some of the vegetables were 200 and $3950 \mu \mathrm{g} \mathrm{kg}^{-1}$, respectively (Bahemuka and Mubofu 1999). Ghasemidehkordi et al.

Table 2 Comparison of the heavy metals content in agricultural products samples with Permissible limit of Iran/EC/FDA ( $\mu \mathrm{g} / \mathrm{kg}$ )

\begin{tabular}{|c|c|c|c|c|c|c|c|c|c|c|c|c|c|c|c|c|c|}
\hline \multirow[t]{2}{*}{$\begin{array}{l}\text { Type of } \\
\text { food }\end{array}$} & \multirow[t]{2}{*}{ samples } & \multicolumn{4}{|c|}{ Mean \pm SD } & \multicolumn{3}{|c|}{$\begin{array}{l}\text { Maximum } \\
\text { permisible level } \\
\text { of EC }\end{array}$} & \multicolumn{3}{|c|}{$\begin{array}{l}\text { Maximum } \\
\text { permisible level } \\
\text { of Iran }\end{array}$} & \multicolumn{3}{|c|}{$\begin{array}{l}\text { Maximum } \\
\text { permisible level } \\
\text { of FDA }\end{array}$} & \multicolumn{3}{|c|}{$p$-value } \\
\hline & & As & $\mathrm{Cd}$ & $\mathrm{Hg}$ & $\mathrm{Pb}$ & $\mathrm{Cd}$ & $\mathrm{Hg}$ & $\mathrm{Pb}$ & $\mathrm{Cd}$ & $\mathrm{Hg}$ & $\mathrm{Pb}$ & Cd & $\mathrm{Hg}$ & $\mathrm{Pb}$ & $\mathrm{Hg}$ & $\mathrm{Pb}$ & $\mathrm{Cd}$ \\
\hline Legume & $(n=60)$ & ND & ND & $35.45 \pm 6.36$ & $562.17 \pm 34.39$ & - & 20 & 300 & - & - & - & - & 500 & 6000 & 0.040 & 0.042 & - \\
\hline /heat & $(n=30)$ & ND & ND & $39.54 \pm 7.26$ & $372.69 \pm 26.35$ & - & 30 & 500 & - & - & 100 & - & 500 & 6000 & 0.025 & 0.030 & - \\
\hline Potato & $(n=30)$ & ND & $27.46 \pm 2.33$ & $17.47 \pm 1.67$ & $470.52 \pm 12.61$ & 30 & 5 & 100 & - & - & 20 & 100 & 500 & 1000 & 0.04 & 0.043 & 0.043 \\
\hline
\end{tabular}


Table 3 Results of THQ indexes due to consumption of $\mathrm{Hg}, \mathrm{Cd}$ and $\mathrm{Pb}$ content in agricultural products samples by deterministic method

\begin{tabular}{lll}
\hline Type of food & & deterministic method \\
\hline Legume & $\mathrm{Hg}$ & 0.092 \\
\multirow{3}{*}{ Wheat } & $\mathrm{Pb}$ & 0.041 \\
& $\mathrm{Hg}$ & 1.733 \\
Potato & $\mathrm{Pb}$ & 0.454 \\
& $\mathrm{Hg}$ & 0.139 \\
& $\mathrm{~Pb}$ & 0.104 \\
& $\mathrm{Cd}$ & 0.043 \\
\hline
\end{tabular}

(2018a, b) determined the concentrations of $\mathrm{Pb}$ and $\mathrm{Hg}$ in 10 kinds of agricultural products from agricultural lands near industrial areas of Iran. The highest amount of $\mathrm{Pb}$ and $\mathrm{Hg}$ reported $56.147 \mathrm{\mu g} \mathrm{kg}^{-1}$ and $1733.62 \mu \mathrm{g} \mathrm{kg}^{-1}$, respectively, which were higher than authenticated regulations of THQ World Health Organization \& Food and Agriculture Organization (WHO/FAO) (Ghasemidehkordi et al. 2018a,b).

Wheat considers as an important cereal in the diet and provides a $50-90 \%$ protein requirement and total caloric content in many countries especially in Iran (Khaniki et al. 2005). The mean $\mathrm{Pb}$ concentration of $\mathrm{Pb}$ in different traditional flatbreads in Iran by Jahed Khaniki et al. (2005), was determined between 270 and $520 \mathrm{~g} \mathrm{~kg}^{-1}$, while the mean Cd concentration was determined as $120-650 \mu \mathrm{g} \mathrm{kg}^{-1}$ (Khaniki et al. 2005). In general, it has been shown that metal contamination in grain bran is more endosperm. Therefore, the amount of toxic metals in cereal-based products like bread is associated with the extraction rate of flour. Furthermore, the supply of wheat from industrial areas can cause further pollution (Khaniki et al. 2005; Tajdar-oranj et al. 2018).

Sadeghi et al. (2020) determined mean concentrations of $\mathrm{As}, \mathrm{Cr}, \mathrm{Hg}$, and $\mathrm{Ni}$ in wheat were $0.186,0.9,0.021$, and $05 \mathrm{mg} \mathrm{kg}^{-1}$, respectively. In this study among the metals, As and Hg were the highest, which may be due to wastewater released from human activity in the area (Sadeghi et al. 2020).

Leblebici et al. (2017) determined lowest and highest levels of $\mathrm{Cd}, \mathrm{Cr}, \mathrm{Ni}$ and $\mathrm{Pb}$ in potatoes were $0.01-1.90$, $0.08-0.98,0.02-5.35$ and $0.52-13.86{\mu g^{-1}}^{-1}$ dw, respectively. These toxic metals can be transferred to the atmosphere, water and soil from the activities of industries, mines, agricultural fertilizers, combustion of fossil fuels and traffic. (Leblebici et al. 2017).

Toxic metal contamination of agricultural products is generally observed in most parts of the world; toxic metals are a serious threat to human health. In general, the main reason for the presence of toxic metals due to the rapid growth of urbanization is the change of agricultural land use to industrial, especially in developing countries (Rai et al. 2019).
Non-carcinogenic risk assessment of toxic metals by intake of agricultural products

The results revealed that the rank order of agricultural products based on THQ was wheat $>$ potato $>$ legume (Table 3). The concentration of $\mathrm{As}$ and $\mathrm{Cd}$ in agricultural products was lower than the limit of detection (LOD), except $\mathrm{Cd}$ in some samples of potato which were lower than the MPLof EC (Commission E. 2006). Therefore, there was no need to estimate their noncarcinogenic risk in the population.

The non-carcinogenic risk of wheat was found higher than potatoes and legumes due to the high consumption rate of wheat ( $320 \mathrm{~g} /$ day). The THQ index of $\mathrm{Hg}$ and $\mathrm{Pb}$ in wheat was 1.37 and 0.454 ; in potato 0.139 and 0.104 ; in legume 0.092 and 0.41 , respectively (Table 3). In Markazi province is a considerable non-carcinogenic risk (THQ $>1)$ due to ingestion of wheat. Because of the high daily consumption of wheat and the persistent nature of toxic metals during food processing and bioaccumulation of them in the human (Stefanović et al. 2008), the associated safety considering the concentration of the toxic metal is highly concern.

\section{Carcinogenic risk assessment of toxic metals by intake of agricultural products}

The characteristic of the cancer risk (CR) can be qualitatively described as follows; safe limit $\mathrm{CR}<10^{-6}$; acceptable limit $10^{-4}>\mathrm{CR}>10^{-6}$; threshold risk limit $\mathrm{CR}>$ $10^{-4}$; considerable risk limit $\mathrm{CR}>10^{-3}$. The findings carcinogenic risk assessment of $\mathrm{Pb}$ in agricultural product samples showed that the CR index was the acceptable limit (>10-4). In various studies, agricultural soil is generally considered to be one of the main sources and receptors for toxic metals. However, in Markazi Province, the presence of toxic metals in the soil may be from various sources such as industrial activities, $\mathrm{Pb}$ and $\mathrm{Zn}$ mines, and fuel combustion, greenhouse gas emissions, and municipal waste disposal.

The excessive entry of heavy metals and synthetic chemicals into the studied soils may lead to deterioration of the soil biology, thereby altering the physicochemical properties of the soil and causing other environmental problems. Increasing air, water, and soil pollution caused by traffic jams, mines, various manufacturing industries, and industrial waste is a serious problem that negatively affects public health (Islam et al. 2020; Proshad et al. 2018; Hani and Karimineja 2010b; Ghiyasi et al. 2010b).

Although the urban structure of this province seems to be advanced, despite the advanced urban facilities, the main problems caused by air, water, and soil pollution of the area may cause pollution in agricultural products of the Markazi Province. Agricultural products are the main food used in many countries of the world, and pollution has been reported in most parts of the world due 
to soil, groundwater, and air. Concerning the increase, the level of heavy metals in agricultural soils and their uptake in agricultural products may be a serious health problem has arisen in some parts of this province.

\section{Conclusion}

The results showed that the concentrations of As and $\mathrm{Cd}$ in all samples (legumes, wheat, potatoes) were lower than LOD, and also the concentration of $\mathrm{Cd}$ in potato samples was less than the MPL of EC. Pb had the highest mean of toxic metals in all agriculture product samples. The concentrations of $\mathrm{Hg}$ and $\mathrm{Pb}$ in all samples (legume, wheat, potatoes) were lower than LOD, and also the concentration of $\mathrm{Pb}$ in wheat samples was lower than the permitted limit of EC. Wheat was recognized as the most important source of exposure to toxic metals due to its high consumption compared to potatoes and legumes. The results of deterministic method showed exposed population from Markazi Province were at an acceptable cancer risk range, by ingestion of wheat and potato samples. Further research to identify the potential sources of contamination with toxic metals and possible control or corrective strategies and continuous monitoring of agricultural products are recommended. Also, farmers, craftsmen, and other people in the community should be aware of the dangers of food exposed to toxic metals in the Markazi province, which can reduce the level of toxic metals in these foods by providing guidelines and action.

\section{Acknowledgments}

This study was part of an MSc thesis of Fereshteh Karimi in Food safety and Hygiene that was conducted in the laboratory of the Department of Environmental Health of School of Public Health, Tehran University of Medical Sciences.

\section{Authors' contributions \\ NabiShariatifar: Conceptualization, Supervision, Design of study Writing- Reviewing and Editing. Fereshteh Karimi.: data analysis, Writing- Original draft preparation. Mohammad Rezaei: data analysis, Investigation. MahsaAlikord: Writing- Reviewing and Editing, Software Majid Arabameri: Software, Methodology, Validation. The author(s) read and approved the final manuscript.}

\section{Funding}

This article does not provide any financial support.

\section{Availability of data and materials}

The datasets applied and analyzed during this research are available from the corresponding author on request.

\section{Declarations}

\section{Competing interests}

The authors have no conflicts of interest to declare in this work.

\section{Author details}

'Department of Environmental Health Engineering, School of Public Health, Tehran University of Medical Sciences, Tehran, Iran. ${ }^{2}$ Vice-chancellery of Food and Drug, Shahrood University of Medical Sciences, Shahrood, Iran.
Received: 4 January 2021 Accepted: 31 May 2021

Published online: 16 June 2021

\section{References}

Abdollahi M, Mohammadi NF, Houshiarrad A, Ghafarpour M, Ghodsi D, Kalantari N (2014) Socio-economic differences in dietary intakes: the comprehensive study on household food consumption patterns and nutritional status of IR Iran

Agrawal M, Singh B, Rajput M, Marshall F, Bell J (2003) Effect of air pollution on peri-urban agriculture: a case study. Environ Pollut 126(3):323-329

Bahemuka T, Mubofu EB (1999) Heavy metals in edible green vegetables grown along the sites of the Sinza and Msimbazi rivers in Dar Es Salaam, Tanzania. Food Chem 66(1):63-66

Bjørklund G, Dadar M, Mutter J, Aaseth J (2017) The toxicology of mercury: current research and emerging trends. Environ Res 159:545-554

Cancer IAfRo (1993) Cadmium and cadmium compounds. Monographs Eval Carcinogenic Risks Humans 58:119-237

Cheng J, Zhang X, Tang Z, Yang Y, Nie Z, Huang Q (2017) Concentrations and human health implications of heavy metals in market foods from a Chinese coal-mining city. Environ Toxicol Pharmacol 50:37-44

Commission E (2006) Commission regulation (EC) no 1881/2006 of 19 December 2006 setting maximum levels for certain contaminants in foodstuffs. Off J Eur Union 364(1):5-24

Dadar M, Adel M, Nasrollahzadeh Saravi H, Fakhri Y (2017) Trace element concentration and its risk assessment in common kilka (Clupeonella cultriventris caspia Bordin, 1904) from southern basin of Caspian Sea. Toxin Rev 36(3):222-227

Dodangeh H, Rahimi G, Fallah M, Ebrahimi E (2018) Investigation of heavy metal uptake by three types of ornamental plants as affected by application of organic and chemical fertilizers in contaminated soils. Environ Earth Sci 77(12):473

EPA U (2015) United States environmental protection agency. Quant Risk Assess Calc 7-9:2015

Fakhri Y, Bjørklund G, Bandpei AM, Chirumbolo S, Keramati H, Pouya RH et al (2018) Concentrations of arsenic and lead in rice (Oryza sativa L.) in Iran: a systematic review and carcinogenic risk assessment. Food Chem Toxicol 113: 267-277

Fakhri Y, Mousavi Khaneghah A, Hadiani MR, Keramati H, Hosseini Pouya R, Moradi B et al (2017) Non-carcinogenic risk assessment induced by heavy metals content of the bottled water in Iran. Toxin Rev 36(4):313-321

Fang Y, Nie Z, Liu F, Die Q, He J, Huang Q (2014) Concentration and health risk evaluation of heavy metals in market-sold vegetables and fishes based on questionnaires in Beijing. China Environ Sci Pollut Re 21(19):11401-11408

Fathabad AE, Shariatifar N, Moazzen M, Nazmara S, Fakhri Y, Alimohammadi M et al (2018) Determination of heavy metal content of processed fruit products from Tehran's market using ICP-OES: a risk assessment study. Food Chem Toxicol 115:436-446

Food and Drug Administration (FDA). Mercury and Methylmercury - Regulated Product(s). Food \& Beverages,Retrieved from https://www.fda.gov/food/meta Is-and-your-food/mercury-and-methylmercury: Universidade de Coimbra; 2018

Ghasemidehkordi B, Malekirad AA, Nazem H, Fazilati M, Salavati H, Rezaei M (2018b) Arsenic and boron levels in irrigation water, soil, and green leafy vegetables. Int J Vegetable Sci 24(2):115-121

Ghasemidehkordi B, Malekirad AA, Nazem H, Fazilati M, Salavati H, Shariatifar N et al (2018a) Concentration of lead and mercury in collected vegetables and herbs from Markazi province, Iran: a non-carcinogenic risk assessment. Food Chem Toxicol 113:204-210

Ghiyasi S, Karbassi A, Moattar F, Modabberi S, Sadough MB. Origin and concentrations of heavy metals in agricultural land around aluminium industrial complex. J Food Agriculture Environ. 2010a;8(3\&4):1237

Hani A, Karimineja M (2010a) Toxic metal distribution in soils of Kaveh industrial city Iran. World Appl Sci J 8(11):1333-1342

Heshmati A, Ghadimi S, Khaneghah AM, Barba FJ, Lorenzo JM, Nazemi F et al (2018) Risk assessment of benzene in food samples of Iran's market. Food Chem Toxicol 114:278-284

ISIRI. Institute of Standards and Industrial Research of Iran, Food \& FeedMaximum limit of heavy metals ISIRI. no12968. 1st. Edition, Karaj: ISIRI; . 2000

Islam MS, Proshad R, Asadul Haque M, Hoque MF, Hossin MS, Islam Sarker MN (2020) Assessment of heavy metals in foods around the industrial areas: health hazard inference in Bangladesh. Geocarto Int 35(3):280-295 
Jahanbakhsh M, Afshar A, Momeni Feeli S, Pabast M, Ebrahimi T, Mirzaei M et al (2019) Probabilistic health risk assessment (Monte Carlo simulation method) and prevalence of aflatoxin B1 in wheat flours of Iran. Int J Environ Anal Chem:1-12

Kalantari N, Ghafarpour M, Houshiarrad A, Kianfar H, Bondarianzadeh D, Abdollahi $M$, et al. National comprehensive study on household food consumption pattern and nutritional status, IR Iran, 2001-2003. National Report. 2005;1(1)

Khaniki GRJ, Yunesian M, Mahvi AH, Nazmara S (2005) Trace metal contaminants in Iranian flat breads. J Agric Soc Sci 1(4):301-303

Leblebici Z, Aksoy A, Akgul G (2017) Accumulation and effects of heavy metals on potatoes (Solanum tuberosum L.) in the Nevsehir, Turkey. Fresen Environ Bull 26(12):7083-7090

Lei M, Tie B-Q, Song Z-G, Liao B-H, Lepo JE, Huang Y-Z (2015) Heavy metal pollution and potential health risk assessment of white rice around mine areas in Hunan Province, China. Food Security 7(1):45-54

Liu X, Song Q, Tang Y, Li W, Xu J, Wu J et al (2013) Human health risk assessment of heavy metals in soil-vegetable system: a multi-medium analysis. Sci Tota Environ 463:530-540

Madani-Tonekaboni M, Rafiei Nazari R, Mirzamohammadi S, Abdolshahi A, Abbasi-bastami N, Arabameri M (2019) Monitoring and risk assessment of Lead and cadmium in milks from east of Iran using Monte Carlo simulation method. Nutri Food Sci Res 6(2):29-36

Marrugo-Negrete J, Durango-Hernández J, Pinedo-Hernández J, Olivero-Verbel J Díez S (2015) Phytoremediation of mercury-contaminated soils by Jatropha curcas. Chemosphere. 127:58-63

Mendil D, Uluözlü ÖD, Hasdemir E, Çağlar A (2004) Determination of trace elements on some wild edible mushroom samples from Kastamonu, Turkey. Food Chem 88(2):281-285

Momen AA, Zachariadis GA, Anthemidis AN, Stratis JA (2006) Investigation of four digestion procedures for multi-element determination of toxic and nutrient elements in legumes by inductively coupled plasma-optical emission spectrometry. Anal Chim Acta 565(1):81-88

Nazaroff W, Alvarez-Cohen L (2001) Environmental engineering science. John Wiley and Sons Inc., New York

Pang W, Qin F, Lyu Y, Li Y, Li G, Li X (2016) Chemical speciations of heavy metals and their risk assessment in agricultural soils in a coal mining area from Xingren County, Guizhou Province, China. Ying Yong Sheng Tai Xue Bao 27(5):1468-1478

Proshad R, Islam MS, Kormoker T (2018) Assessment of heavy metals with ecological risk of soils in the industrial vicinity of Tangail district, Bangladesh. Int J Adv Geosci 6(1):108-116

Pruvot C, Douay F, Hervé F, Waterlot C (2006) Heavy metals in soil, crops and grass as a source of human exposure in the former mining areas (6 pp). J Soil Sediment 6(4):215-220

Qu C-S, Ma Z-W, Yang J, Liu Y, Bi J, Huang L (2012) Human exposure pathways of heavy metals in a lead-zinc mining area, Jiangsu Province, China. PLoS One 7(11):e46793

Rahman MM, Azirun SM, Boyce AN (2013) Enhanced accumulation of copper and lead in amaranth (Amaranthus paniculatus), Indian mustard (Brassica juncea) and sunflower (Helianthus annuus). PLoS One 8(5):e62941

Rai PK, Lee SS, Zhang M, Tsang YF, Kim K-H (2019) Heavy metals in food crops: health risks, fate, mechanisms, and management. Environ Int 125:365-385

Raj D, Maiti SK (2019) Sources, toxicity, and remediation of mercury: an essence review. Environ Monit Assess 191(9):566

Rezaei M, Shariatifar N, Jahed Khaniki G, Javadzadeh M (2013) Nitrite in hamburgers in Arak, Iran. Food Additives Contaminants: Part B 6(4):285-288

Roudbari A, Rafiei Nazari R, Shariatifar N, Moazzen M, Abdolshahi A, Mirzamohammadi S et al (2021) Concentration and health risk assessment of polycyclic aromatic hydrocarbons in commercial tea and coffee samples marketed in Iran. Environ Sci Pollut Res 28(4):4827-4839

Sadeghi M, Noroozi M, Kargar F, Mehrbakhsh Z (2020) Heavy metal concentration of wheat cultured in Golestan Province. Iran and Its Health Risk Assessment, Journal of Environmental Health and Sustainable Development

Salama AK, Radwan MA (2005) Heavy metals (cd, Pb) and trace elements (cu, Zn) contents in some foodstuffs from the Egyptian market. Emirates J Food Agriculture:34-42

Sarkar A, Paul B (2016) The global menace of arsenic and its conventional remediation-a critical review. Chemosphere. 158:37-49

Sharafi K, Yunesian M, Nodehi RN, Mahvi AH, Pirsaheb M (2019) A systematic literature review for some toxic metals in widely consumed rice types (domestic and imported) in Iran: human health risk assessment, uncertainty and sensitivity analysis. Ecotoxicol Environ Saf 176:64-75

Shariatifar N, Mozaffari Nejad AS, Ebadi FA (2017) Assessment of heavy metal content in refined and unrefined salts obtained from Urmia, Iran. Toxin Rev 36(2):89-93

Shariatifar N, Rezaei M, Sani MA, Alimohammadi M, Arabameri M (2020) Assessment of Rice marketed in Iran with emphasis on toxic and essential elements; effect of different cooking methods. Biol Trace Elem Res:1-11

Solgi E, Esmaili-Sari A, Riyahi-Bakhtiari A (2014) Spatial distribution of mercury in the surface soils of the urban areas, Arak, Iran. Bull Environ Contam Toxicol 93(6):710-715

Solgi E, Esmaili-Sari A, Riyahi-Bakhtiari A, Hadipour M (2012) Soil contamination of metals in the three industrial estates, Arak, Iran. Bull Environ Contam Toxicol 88(4):634-638

Stefanović VŽ, Filipović NK, Jovanović BM (2008) Undesirable metals content in wheat of different wheat varieties. Acta Periodica Technologica APTEFF 39:1212

Tadesse B, Atlabachew M, Mekonnen KN (2015) Concentration levels of selected essential and toxic metals in potato (Solanum tuberosum L.) of west Gojjam, Amhara region, Ethiopia. SpringerPlus 4(1):514

Tajdar-oranj B, Shariatifar N, Alimohammadi M, Peivasteh-roudsari L, Khaniki GJ, Fakhri Y et al (2018) The concentration of heavy metals in noodle samples from Iran's market: probabilistic health risk assessment. Environ Sci Pollut Res 25(31):30928-30937

Torres-Escribano S, Vélez D, Montoro R (2010) Mercury and methylmercury bioaccessibility in swordfish. Food Addit Contam 27(3):327-337

Türkmen M, Dura N (2016) Assessment of heavy metal concentrations in fish from south western black sea

USEPA. U.S. Environmental Protection Agency, Supplemental guidance for assessing susceptibility from early-life exposure to carcinogens. http://www3. epa.gov/airtoxics/childrens_supplement_final.pdf (Accessed on January 25, 2016). 2016

Yılmaz AB, Sangün MK, Yağlıoğlu D, Turan C (2010) Metals (major, essential to non-essential) composition of the different tissues of three demersal fish species from Iskenderun Bay, Turkey. Food Chem 123(2):410-415

Yousefi M, Shemshadi G, Khorshidian N, Ghasemzadeh-Mohammadi V, Fakhri Y, Hosseini $\mathrm{H}$ et al (2018) Polycyclic aromatic hydrocarbons (PAHs) content of edible vegetable oils in Iran: a risk assessment study. Food Chem Toxicol 118 480-489

\section{Publisher's Note}

Springer Nature remains neutral with regard to jurisdictional claims in published maps and institutional affiliations.

Ready to submit your research? Choose BMC and benefit from:

- fast, convenient online submission

- thorough peer review by experienced researchers in your field

- rapid publication on acceptance

- support for research data, including large and complex data types

- gold Open Access which fosters wider collaboration and increased citations

- maximum visibility for your research: over $100 \mathrm{M}$ website views per year

At $\mathrm{BMC}$, research is always in progress.

Learn more biomedcentral.com/submissions 